
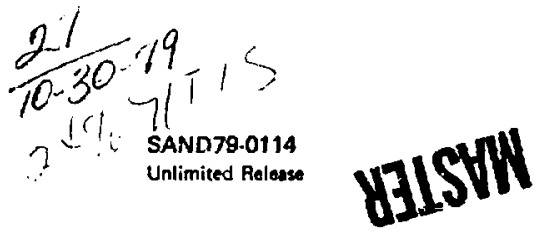

\title{
Indirect Deformation (Strain) Measurements and Calibrations in Sandia Triaxial Apparatus for Rock Testing to $250^{\circ} \mathrm{C}$
}

Wolfyang R. Wawersik

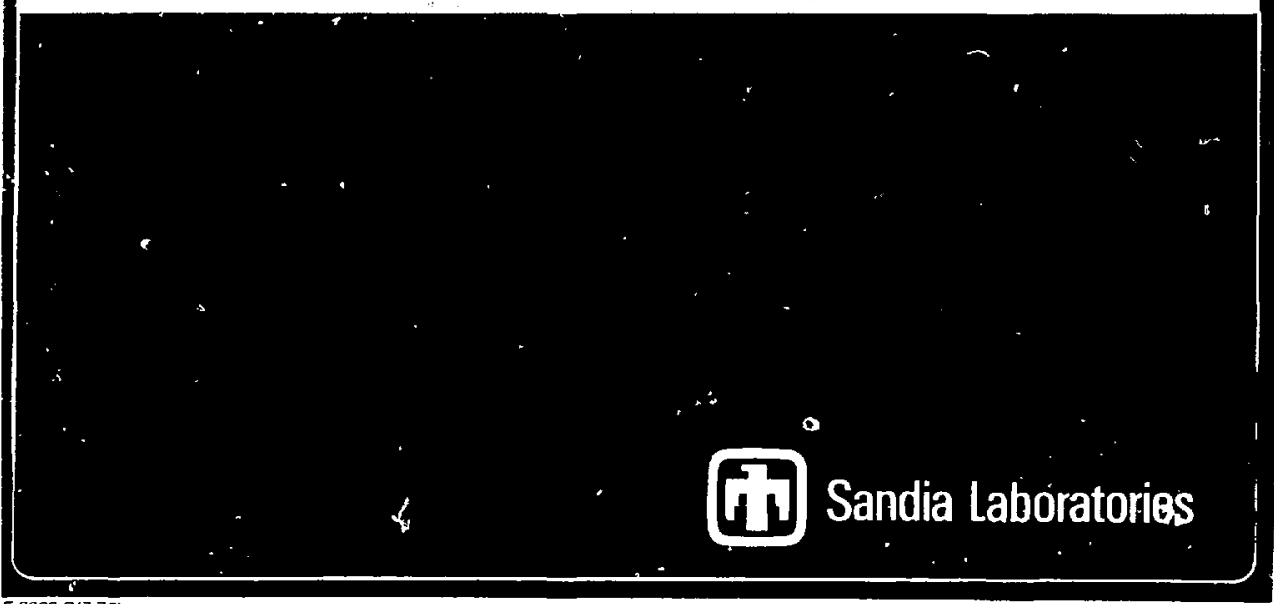




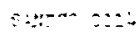

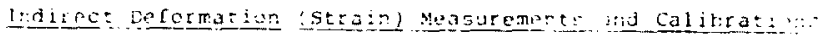

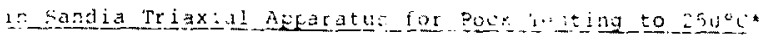

by

hi. R. Wawersik

Santia baboratories**

Albuguergue, wow sexico sillit

\section{ADSTRACT}

Indifect procedures for axial and radial strain measurements on rock in triaxial tests $10250^{\circ} \mathrm{C}$ are presentes. The desrrition of technigues includes discussions of all calibrat.ons and of tro accuracies of measurements. In addition, two examples ars qi $\because n$ to show low the technigues are mplemented an triaxinl compressarn and triaxial extension experiments.

"This work was supported by the U.S. Department of Fnergy (DuE; vivisiul of kaste Management (ETW), linder contract DE-4:04-76DP00789.

* * U.S. nOE tacility.

DESELAikt I 
LNTROOUCTION

B!"VIFU OP TRIAXIAI EXPERIMENTS

AX:AL DEFORTATION (STRAIN) MEASUREMENTS

tho Mrenodi

vithratians.

Pontormination of Platen Displacement

("imionent o'PI, *. .

Foter.ination of Platen Disulazement

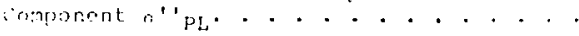

Pealution and Accuracy of Measurement. . . . .

I. OML (RADIAL) DEFORMATION MEAEURENEHTS. . . . . .

Metror : - king Transducer. . . .........

sethod. - Dijatometric Heasuremert. . . . .

cose

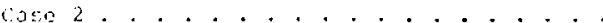

Corractions for rests at E] ratgid Pomperaturn. . low f.rad inrrfetions. . . . . . . . . . . .

iolibrations for Dilatometric Mathod.

Rosolutinn and tacentacy of Dilatemotric

$\because 1$ isurements.

i: I.EMENTATLON OF MEASUREMENT TFCIINICUES - EXAMPLFS. -

Btrain Compltations in Triaxial cumpression

Trast at constant confinina Pressure. . . . .

Sitrain Computations in Triaxial Fxtension Tests

at voriahlo confining oressure.

SI:MMARY.

BHERENCE;

FI JURES 


\section{ILLUSTRATIONS}

Fingra l. . . . . . . . . . . . . . . . .

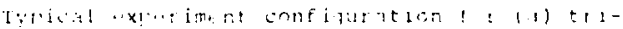

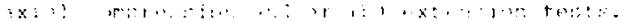

Fin:is

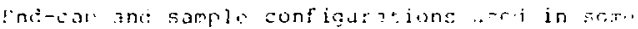

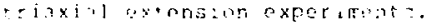

Fi j:iris 3

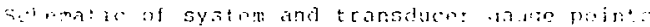

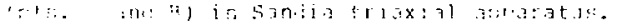

Fianto:

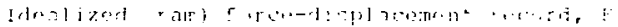

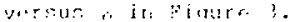

Fing:1, :

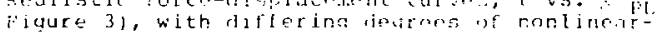

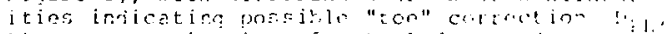
i inear acproxifacior of actual datr jal isextru"

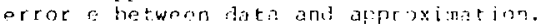

Figure 6

Actual (a) and ateolized (b) fored that aceme pl

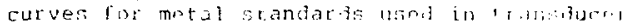
and syetare calitrations.

Fintise 7

Schematic of tauge point tramefor lu! tom for measuroment of radial samplo dolot tritisn.

Figuro 8

Typical surface profi]e of coformar luek salt specimen paraliel to sample $x \mathrm{ja}$ lijir+ition of is)

$x$ : Distance [rom simevimen arit:

$y$ : Relative ampliturif propgrtinfal to ratial droformation $\left(1.13 \times 10^{-3}\right.$ in $(2)$. $\left.4 \mathrm{~m}\right)$ !... smallest division).

Records $\$ 2$ and \#3 worrespond to dande lines radians apart. 
Fioure 9

Schematic of triaxial sample - piston arrangement with matched diameters, $D_{R}=D_{S}$ for interpretation of dilatometric reasurements.

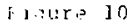

Schematic configuration of spezimen, loading Fiston, ane end-caps in Sandia triaxial apparatus. Ports tirough piston and end-caps provide access to specimen for venting, pore pressure cortrol, etc. 

Sanjia triaxial apparatus. At the same time, this report provides a manual for those who wish to use the equipment. It is divided into four parts: (1) a general review of triaxial compression and extension tests, (2) a description of axial strain Toasurements on rock cylinders, (3) a discussion of radial strain measurements, and (4) two examples which demonstrate how the messurement techniques are implemented in particular experiments. 


\section{REVIEW OF TRIAXIAL EXPERIMENTS}

A brief revi:w of so-called triaxial experiments is given here to avoid confusior among users who are unfamiliar with $20: \%$ testiny. The name triaxial test defines two types of experiments which are performed on cylindrical specimens such that two principal stresses are always equal. Denoting compressive stresses as positive the [ullowing conditions can be ohtained: (1) ${ }^{r}{ }_{1}: \sigma_{2}=\sigma_{3}$ or $(2) \sigma_{1}=\sigma_{2} \geq \sigma_{3}$. Case one is called triaxial compression. Cace two is known as triaxial extension wherc $r_{3}$ may, but does not have to be tensile (negative). In the nonEnglish literature both types of triaxial tests are often referrei to as von kármáii experiments.

To produce states of triaxial compression or extension, tyoically rock cylinders are positioned between arvils, jacketed and placed inside a pressure vessel as shown in $r$ iqure 1 . Fach specimen can be subjected to hydrostatic and deviatoric loadin. Hydrostatic loading is accomplished direct?y in Figure la by pressurizing the pressure vessel. Alternatively, for the sotu! in Figure lb hydrostatic pressure may be jeneratea by applyia: simultaneously a ran force, F, and a pressure, p, inside the vessel. The schenatic in Figure $1 b$ indicates that the pressurizing rejiun (liquid or gas) does not enter the interface betwor. the loading piston and the specimen ends. Therefore, tho applicl radial pressure and the axial stress are decoupled; this is neaczsary to conduct triaxial extension experiments.

neter a hydrostatic stress state is induced, deviatoric loading can commence as triaxial compression or triaxial ex- 


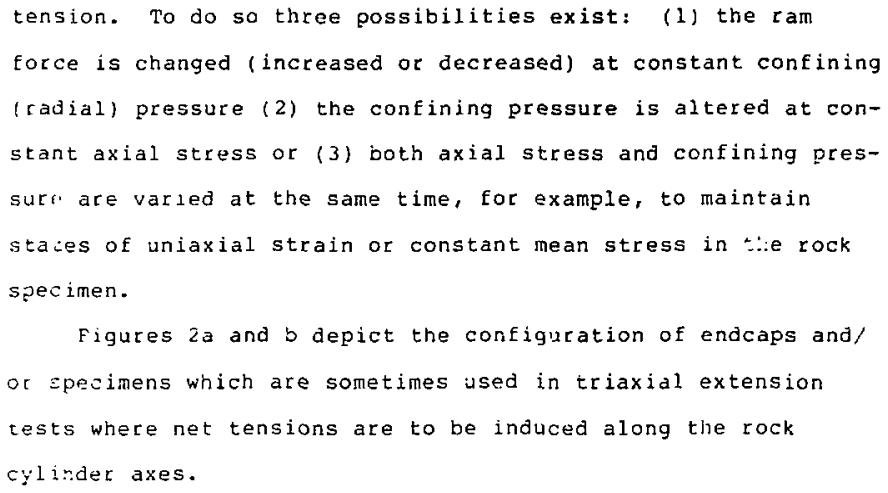




\section{AXIAL DEFUKMATIUN (STRAIN) MEASUREMENTS}

The Method

Axial rock deformation in the sandia apparatus is masurol by means of one or two Linear Variable Differential Transforners (LVDT) extornal to the pressure vessel (Figure 3 ). The transAucers track the relative displacements between one or two sute of points, $A$, or the loading piston and on reference points, B, at one end of the pressure vessel.

For the experiment setup in Figure 3, changes in position $d$ between the palrs of points $A$ and $B$ are user +1 conipute the changes in length, $\dot{n}_{K}$, of the rock sample which is subjected to an axial force $F$ and confining (hydrostatic) pressure 0 . Tho? temperature of the experimental system is arbitrary but aseumea constant. The rock deformation is cbtained by subtracting all non-rock contributions from the total measured displacenent. The total non-rock contribution will be called "platen isplacenent, " ${ }_{\mathrm{PL}}$. It derives from the deformation of end-caps, 10aant pistons and interfaces, $\delta_{P t}$, with varying $F$. It is also affected by changes in the length of the pressure vessel, "PI, with changes in pressure p. This,

$$
\delta_{\mathrm{R}}=\hat{\delta}-\hat{\delta}_{\mathrm{PL}}
$$

where

$$
i_{\mathrm{PL}}=\hat{i}_{\mathrm{PL}}+\dot{ } \cdot \dot{\mathrm{PL}}
$$

If two diametrically opposed transducers are employed then $i$ represents average displacement readings. This avorage elini- 
nates some or all of the influence of piston ratations. If only one transducer is utilized it is essential that the rock sample he rnachined to close tolezances and that the test system be arcurately aligned.,

poth $\lambda_{P L}$ and $\dot{r}_{\mathrm{PL}}$ mist be determined by caliblation. Calirations art mandatory to establish $\hat{n}_{\mathrm{p}}$ because of the nonlinear force-fisplacement behavior of various interfaces between rock socciren and end caps etc. as indicated in Figure 3.

once $i_{R}$ is known, the axial rock strain, ea is calculated as $\varepsilon_{a}=\frac{\delta_{k}}{L_{k}}$, or $\quad \varepsilon_{a}=-\ln \left(1-\frac{\delta_{k}}{i_{R}},\right.$.

Js!ng the iritial specimen length, $L_{R}$. In either case compressive strain is denoted positive. The two strain definitions $\therefore$ sio so-called enaineering strain and true (lograthmic) strain, :ospertively. Note the tacit assumption that the ro." feformation 1: homogeneous along the sample axis. Although this condition Hres not ordinarily prevail, it can be approached by the choice of appropriate ratios of sample length to sample diametor.

\section{Calihrations}

ir.- artination of Platen Displacement Component "PL

Platen displacement calibrations are carried out by moans of steel and aluminum stanfards of identical size and of knovn voung's moduli and poisson's ratios. If these standards are tostod in lieu of a rock sample, ideally, linear records are critained of force, F, versus total displacement (Figure 4). Urider such conditions $b_{\mathrm{PL}}$ can be defined readily in terms of 
an average salibration factor

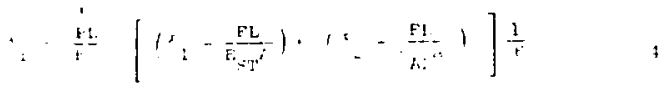

Ihe ruantities $o_{1}$ and $\delta_{2}$ are the total disolacements for ${ }^{\prime}$ a trations on steel ana? aluminum. The subsetipt 5 "sT" anil "Al.

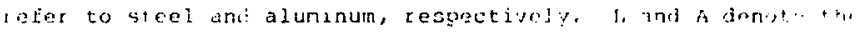
equal lencitis and the cross-sectional areas of the metal st th. dards. As a prociution, area A should be approximately oy.. the cross section "l area of prospective rock specinens. Hu:

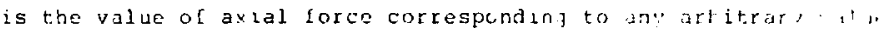
of displacement $\delta$.

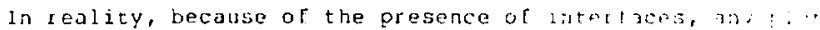

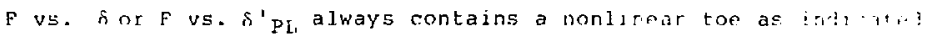
schematicaliy in Figure 5a. This ton reilits fron thr clot..... interfaces at $F \leq E_{c}$. It can seriously affect tor accur at:

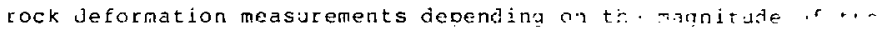

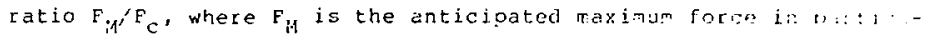
lar experiments of interest (Eigure 5). If $\vec{r}_{4}$ and $\mathrm{r}_{\mathrm{i}} \mathrm{ha}: \mathrm{.}$. same order of magniturie; then $\delta_{P L}$ canrot we detertinfer. ...

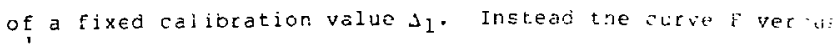
"PL is described by a suitable nonlinear curve fit. In ari: +..., the reletionship between $F$ and $\delta_{p L}$ is recorded in reveated $\ldots .$. on steel, aluminum, and brass standaros ro define the unctra-

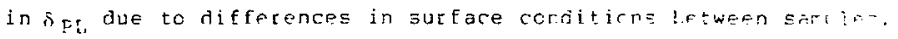

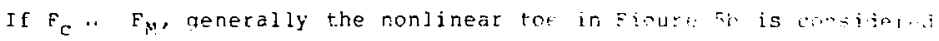
iny means of a single displacement offset 1 -rpe: in the intain: $0 \leq F \leq F_{C}$ (Fiqure 5b). Then the straight line slope is rt.t.?. using Equation (4). 
If errors in rock deformation $\varepsilon_{R}$ on the order of 3-108 can be tolerated, the following third choice exists. A curve F versus ipL which is nonlinear throughout can be approximated by a linear Eit for $F$, F while the highly nonlinear toe within $0 \leq P \leq F_{C}$ is eliminated by a correction $\left(-D_{\mathrm{PL}}\right)$ as shown in Figure 5c. In this case calibration: nust yield the value of the maximum possible error in deformation, e, for $F \leq F_{m}$ (Figure se). The error e constitutes the maximum error between actual readings and their linear approximations.

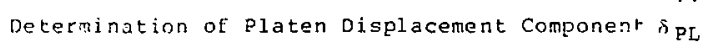


is registered, thus contact between calibration sample and loading piston is reestablished and the change in the gauge lenoth, $\delta$, between points $A$ and $B$ is recorded. This procedure is rarmatm in at least five steps up to the maximum operating proscir: of the system. For linear relationships between $F, 0$, and, , $h$. resulting data for steel, for example, can he related to 1031 bration Eactor

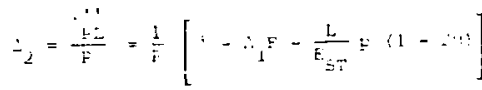

$p$ and $\delta$ represent arbitrary values of pressure and def $\ldots, \cdot$ inr. $F$ equals the sum of the contact force, $F_{0}$, plus the piston reartion, $F_{H}$, du? to D. $s_{1}$ is given by equation (4).

\section{Resolution and Accuracy of Measurement}

The resolution of axial deformation (strain) measurementr as described depends on the resolution of the transducers mployed and on the quality of signal conditioners and recordina squipment. The resolution of LVDT transducers is unlimited. On the gtrer hand, the accuracy of measurement is directly related , wth $\cdots$ number and the condition of interfaces within che activ 10uas length and to the alignment of the entire experimental loas trai-. Interfaces ard misalignment lead to nonlineat readinas which were d2scussed previously.

The accuracy of axial deformation (strain) measurenentis in the Sandia apparatus was ascertained in two ways. First, the corbination of force-displacament records for steal and aluriram was used to calibrate the LVDT transducers. This proceijure was 
Aescribed by Fairhurst (1961) and is indicated in figures $6 a$ and h. Figure $6 a$ depicts the schematic of typical force-displacenent records. Figure $6 \mathrm{~b}$ shows the same curves minus "toe" corrections, (DPL). Hexe force is defined in counds, anc ilsplacement equíls the transducer output in volts. Because the ci.ensions (A, $L$ ) arci the elastic moduli, $E_{S T}$ and $E_{A L}$, of the two standards are known, Finure $\dot{b}$ implies a LVDT calibration factor

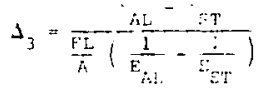

The value of $\lrcorner_{3}(e g .6)$ was then compared with that value, $\overline{3}_{3}$, which was established by airect calibration using a micrometer. is an example, a typical compari: , showed

$$
\begin{aligned}
& s_{3}=1.025 \text { (v/in) } \\
& \bar{s}_{3}=10.000 \text { (v/in) }
\end{aligned}
$$

Hence, the discrepancy was only 0.258.

$$
\text { Referring back to Figures } 5 \text { and } 6 a \text {, a more rigorous way to }
$$
evaluate measurement accuracy follows from a detailed evaluation of the consistency of necessary "toe" corrections, $D_{F L}$, and of Dossible nonlinearities atove the force $F_{c}$. Such checks were again performed by means of a steel standard for which errors become most apparent berause of the high elastic modulds, $\mathrm{E}_{\mathrm{ST}}$. omitting details, the foregoing comparison provided maximur and typical errors in measured displacement of $e_{\max }=4 \times 10^{-4}$ in $(0.01 \mathrm{~mm})$ and $e_{t y p}=2 \times 10^{-4}$ in $(0.005 \mathrm{~mm})$, respectively. These numbers translate into axial strains of $5 \times 10^{-5}$ and $2.5 \times 10^{-5}$ 
for eight inch long samples. In some cases these accuracies can

be improvec, partic. "zrly during deviatoris unloading and rolosidin?

cycles which are often used to determine rlastic rock cunctirt.

It is emphasizen that the accuraciez which are roportiol hir: were attained only after careful aliunant of all appar.s. 1 .

Qualizy align ent is especialiy important for tosts on row with high elastic moduli. 


\section{IATEPAL (RALIAL) DEFORMATION MEASURFMENTS}

\section{Method 1 - Ring Transducer}

In many tests radial rock deformations are measured by means

n[ one or two ing transducers which are suspended at various

i! thencer from the speciren ends. The transducer was developed an: iescribed by schuler (1978). Since each specimen is enclosed $\because=106^{\prime \prime}(1.6 \mathrm{~mm})$ thick, compliant jacket, appreciable errors in

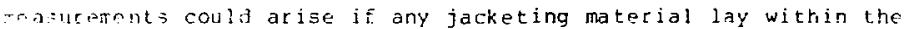
artige dauge lengti of the transducers. To avoid this problem, :ae:ial burtons are utilized which are inserted through holes in tris jackrt as ehown scheratically in Figure 7. The circ transducers employed are remartabiy compact and have a relatively iarge linear range. They are also well suited in montor diameter chanaes at rifferent points on the specimen ircutference. However, if the rock deforms inhomogeneously then readings provided by individual transducers nay differ consilerably from the averace diameter changes along the specimen hoight. This point is demonstrated by the record of a delormed s.ample after testing in Figure 8 .

ynthod 2 - Dilatometri . Measurement

The dilatnmetric method is applied readijy to track avarage radial rock deformation in triaxial experiments at constant conrining pressure. The principles of the method are described elsewhere (Wawersik, 1975). In a leakproof system radial deformation can be calculated from volume adjustments of the confining pressure medium which are needed to keep the confining pressure con- 
stant. Detailc ot the method are eusily explained by means of figure j. Fioure 3 shows the schematic nf a cylincil cal rock sarple hetween cvlindrical loarinn ristons iarita 3 oresul.

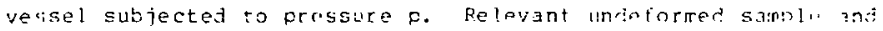

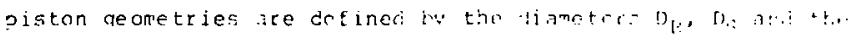

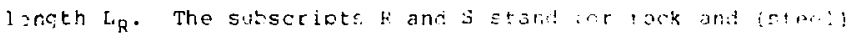
aistons. The alastic constants of tho fiston matarisl a! ! ?n. $\boldsymbol{\nu}_{3}$. The internal lenath of the pressure yosal hetwon the sid and the vessel bot tom is denoted $\mathrm{t}_{1}$ :

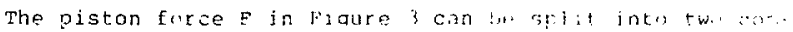
ponents, $F_{H}$ and $F_{D}$. $F_{H}$ constitutes the roactinr to tin ingarro

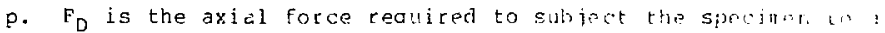
deviatoric stress and is proportional to the difforen... it maximim and minimum principal sam] compressinn, $\left(r_{1}-p\right)=\left(r_{1}-r_{3}\right)$.

Case 1

Consider the axisymetric confialration (.f "yours a wrexn rock and loading piston have equal maeforned sianters $r_{i}=r_{g}$

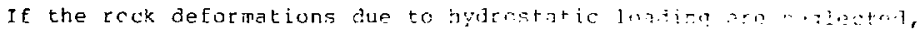

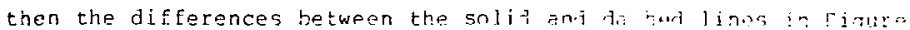

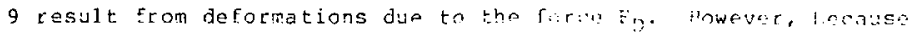
of friction along the rock/piston interlaco, the reloriper spocimen will not be a perfect cylinder but moce or lops parrel-chabra. Therefore, the cylindrical configuration whish is indicated only corresponds to the eouivalent deformed shame at constant diametor which, together with the same axial shortenina, gives rise to the correct volumetric defornation of the socimon. 
Since fluid is displaced with the application of Foe the volume of the confining peessure system must be afjusted to maln1 sin the confining pressure constant. Treating compressions as Fwitive, riques a imolies that this volume adjustent, IV, under lateromal condilions is

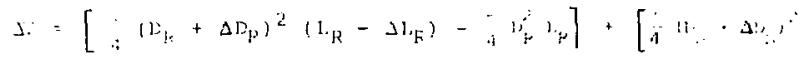

$$
\begin{aligned}
& \cdot\left(u_{\rho}-L_{R}+2 L_{R}\right)-\vec{i} D_{S}^{2}\left(L_{p}-L_{R}\right) j
\end{aligned}
$$

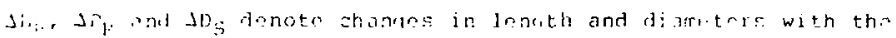

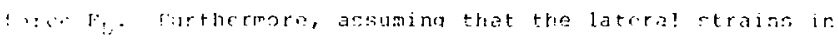
i s: snd siston ate homogeneous:

$$
\left(\leqslant{ }_{2}\right)_{R}=\left\langle\epsilon_{3}\right\rangle_{R ;}\left(\epsilon_{2}\right)_{S}=\left(\epsilon_{3}\right\rangle_{S}
$$

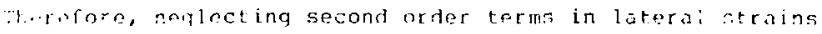

$$
\begin{aligned}
& \left.\Delta V=D_{k}^{2} \mid i 1+2\left(e_{2}\right)_{1} !\left(L_{1}\right)-\Delta I_{R}\right) \\
& +11+2\left(t_{2}\right)_{S}\left|\left(l_{P}-L_{R}+I_{R_{R}}\right)-L_{P}\right| \text {. }
\end{aligned}
$$

iutwititutin's

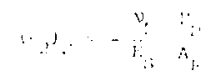

:-ntting

$$
t_{2}=\left(t_{2}\right)_{R} ; \quad t_{3}=\left(\epsilon_{3}\right)_{R}
$$

and onitting simple algabra it follows that

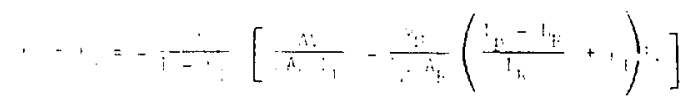


where

$$
A_{R}=\ddot{\prime \prime} D_{R}^{2}=\ddot{i} D_{S}^{2}
$$

und

$$
! \quad \frac{i}{i k}
$$

To consider higher oriter tarms in the stroins $\epsilon_{2}=\epsilon_{3}$, 0.t. (10) can be corrected to sintain

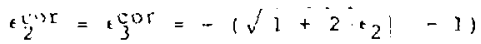

Neqlecting the effoci of hydrostatic lcading generally rosults in errors of less than $.5 x$. If such an exror is excessive it is: $13: ;-$ sible to make appropriate corrections. The difference betwron $\epsilon_{2} \operatorname{cor}$ and $\epsilon_{2} i s+0.5 q$ at $\epsilon_{2}=-I \%$. It increasen rapidly to $+13.2 \%$ at $\epsilon_{2}=-308$.

Case 2

In most experiments at Sandia Laburatoriers the experimental gennetry of piqure 10 is more typical. In this case the rock sample is jacketed between end-caps. Naso, the piston diamotor ia smaller than the diuneters of both rock sumuln and onituas. Lastly each end-cap is equipped with a sealed nipple of aiameter $D_{N}$, to vent the specimen (Fig. 10a).

Idealizing Figure loa and neglecting deformations due to hydrostatic loading again, Fiqure lub leads to isothermal ynlume adjustments, JV, Eor constant confining pressure experiments. specifically, if 


$$
\begin{aligned}
& \lambda_{g}=i D_{R}^{2} \quad E_{c}=E_{S} \\
& \dot{A}_{S}={ }_{i} D_{C}^{2} \quad \nu_{C}=\nu_{S} \\
& \left.A_{C}=\overline{4} D_{S}^{2} \quad\left({ }^{\circ}\right)_{R}^{2}=\left(\epsilon_{2}\right)_{5}^{2}=\left({ }^{*}\right)^{2}\right)^{2}=0 \\
& n_{c}=\Lambda_{R} \quad t_{2}={ }^{6}{ }_{3}=\left(\epsilon_{2}\right)_{R}=\left({ }^{3} 3\right)_{R}
\end{aligned}
$$

revious logie y ba ds

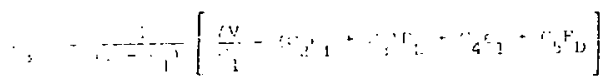

whin. ormprasive strains are positive and

$$
\begin{aligned}
& \therefore=2 n_{k} \cdot R_{R} \\
& \mathrm{C}_{4}=\frac{1}{2}\left(1-\frac{i}{i_{1}}\right) \\
& c_{2}=\stackrel{\nu}{\cdots} \\
& c_{5}=\frac{L_{C}}{1 E_{S}}\left(1-\frac{n_{C}}{n_{k}}\right) \\
& c_{3}=c_{2}\left(\frac{b_{1}}{L_{k}}-1\right)
\end{aligned}
$$

Invluding second order terms $\left(\epsilon_{2}\right)^{2}$, the corrected rosult becomers

$$
{ }_{2} \cos =\frac{\cos }{3}^{2}=-\left(\sqrt{i}+2 ; \epsilon_{2}:-1\right)
$$

Nipte that the dominant terms in $\Delta q$. (12) are $\frac{t_{1}^{*}}{1}$ and $c_{4} \cdot 1$.

Corrections Enr Test at Elevated Temperature"

fors. (10) and (12) apply directly to tests at elovator temnrrature if the volure adjustments can be affected without changin'j the temperature of the confining pressure fluid. This is not 3) ways possible uor is it necessarily advantageous. In the sandia solif, triaxial tests at nevated temperature are performed in auch a manner that only the pressure vessel is heated. The dila- oreter which is used to reculate pressire and to measure $J V$ remains at embient temperature. Thus, when a volume adjustment 
is made, hot rluit is extracted from the vessel or cold fluid injected jetn th. pressure vessel depending on the sign of the fof urmation-indurod prinssure change. To account for thermal contractions or nxpansions, the actual volume adjustnient JV is calculated from the reaistered volurf change $s V_{M}$ as

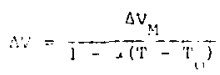

if denotes the coelficient of volumetric thermal expansion of the confining pressure fluid per ${ }^{\circ} \mathrm{C}$. $\mathrm{T}_{1}$ and $\mathrm{T}_{\mathrm{O}}$ are the test temperature in the pressure vessel and the ambient reference: semperature in ${ }^{\circ} \mathrm{C}$, respectively. "he factor a is evaluatod in separate calibration tests as a Eunction of temperature and pressure.

\section{Low Losd Corrections}

Corrections are necessary if the confining pressure rluit can enter any of the intertsies between the specisen ends ard tho loading piston or spacers (Figure la). Fluid is expelled rruin these interfaces as they are closed with increases in ran force. This fluid displacement contributes to an increase in conlinin: pressule which is uncelated to specimen deformation. Thereforo, it introduces an error in dilatometric readings whlch manifosts itself in terms of a nonlinear toe if force is plotted versus dilatometer output. The easiest way to cotrect this error is by a toe adjustment analogous to the toe adjustment $\left(-D_{P L}\right)$ which was described in an earlier section on axial deformation measurements (Fiqure 5). The upper bound and the uncertainty of 
rlis toe adjustment must be evaluated in calibration tricts by me ans of the tal standirds.

\section{Caliorations for Dilatometric Method}

In principle, dilatometric strain measurements can be perfarred without calibrations because the reduction equations devert only on krown geometric porameters and on the known pronotios of all pressure vessel naterials. However, in peacticn alijration tests are recormened to demonstrate tie valicity if rys. (10) a:3 (12). This can be accomplishet hy validating tot: magnitudes of $C_{j}=2{ }^{\circ} \cdot L_{R}$ and of $L_{P}$, which can be detormined iy means of eq. (12) usirg measured volume changes, $\$ V$, and calculated (theoretical) strain values $\epsilon_{1}$ and $\epsilon_{2}=\epsilon_{3}$. Usinn steol and aluminum standards again,

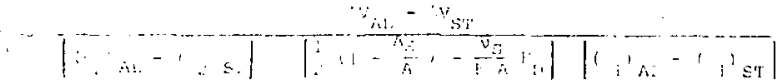

$V_{A I}$ and $V_{S T}$ are measured dilatometric resdings for aluminum and isecl, respectivejy. $E_{5}$, $\nu_{S}$ are assumed to be known. (E I ${ }_{A L}$, $\left(\epsilon_{2}\right)_{A L}$ ( $\left(\epsilon_{1}\right)_{S T}$ ' etc, are the calculated strain magnitudes for the ites 1 and aluminum standacos subjected to the axial corce $F_{D}$. Onces $C_{1}$ is determinnd $t_{p}$ can he found by sunstituting the neasurer values $\$ V_{A L}, J V_{S}$ and the calculated values $\left(\epsilon_{I}\right)_{A L}$, (t ${ }_{2}$ 'sT $t$ ts., into ed. (12). Finally, cemperatuce corrections according to ec. (14) can be validated by repeating somis calibration runs at elevated temperature. To accomplish this with roeptable rasolution, tre nost complant standard available shoula be employod. 
Calibrations in two large sample Sandia apparatus rendered values of $C_{1}$ which agreed to better than 0.1 with the theoretical value $c_{I}=2 A_{R} L_{R}$. In turn, the average calibrater valur OI $L_{n}$ was $13.39 \mathrm{in}(34.01 \mathrm{~cm})$ versus $L_{p}=13.50$ in $(34.29 \mathrm{~cm})$ according to design drawings. This discrepancy of aporoxiratn?y 1 causes an error in measured radial strains of less than $n .1 z$. Ressolution and Accuracy of Dilatometric Measurements

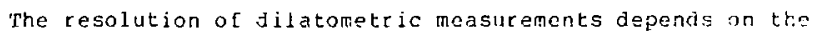
cesolution of small departures away from a reference prosuse and on the bility to make smali volume adjustments, $\Delta V$. To maxithize the cesolution it is advisable to neasure pressura chungr hetween 2 psi $(14 \mathrm{kPa})$ and $10 \mathrm{psi}(69 \mathrm{kPa})$. Furthermore it is necessary to balance the specimen size, the fluid capacity of: the confining pressure system, the dilatometer dimensions and the required response time of the apparatus. At present the sandia equipment. allows reliablo vorino resolutions ar $\Delta V=2 x a^{-3} i^{3}$ (3.. $\left.\mathrm{mm}^{3}\right)$. Thi: roxiesponds to $\left.\left(\epsilon_{2}\right) \mathrm{sT}=1 \epsilon_{3}\right)_{\mathrm{ST}}=10^{-5}$ for $\mathrm{i}=$. 8 i i $(24 .: \operatorname{cm})$ and $n=11.3 \mathrm{in}^{2}\left(76.1 \mathrm{~cm}{ }^{2}\right)$.

The accuracy ot dilatometer measurements is more difficuit to deternine. Obviously, the absence of loaks is mandatory. Besicies that, the messurement accuracy depends on whether tro temperature of the confining pressure fluid remains constant of not. Temgerature changes result in significant thermal expansign and erroneous dilatcmeter adjustments. Deformation induced tenperature changes us dally are nerigible. On the other hand, diurnal temperature changes arouni the Sanija apparatus leas to 
apearent short-term and long-term strain variaticns between $5 \times 10^{-6}$ and $2 \times 10^{-4}$, respectively. Because of the diurnal natire of long-term temperature changes $\left( \pm 0.8^{\circ} \mathrm{C}\right)$ the average ercor is considerably smaller than $2 \times 10^{-4}$.

The accuracy of dilatometric measucements is also a farcion of the homoconeity of specimen deformation. Because of end e[fects most specimens will barrel to qreatro or lesser extent. ?'terefora, the radial strain readings obtained by means of eqs. (10) throuch (13) only provide average strain values. These iverages are lower bounds of the radial strains across the larjest specimen diameter. However, it should be horne in mind that maximun diameter changes, usually at the center of each specinon, are therely upper bounds of the radial strains which would result if the anme resultant forces had produced homoqeneous 5 tates of Heformation (Ralial!, 1973). it is also noted that slight materia! inhorogeneities, for example in rock ralt, mav load to jmerfec: barreling. Gs a result maximu radial strains becur away from the speciren center. This fact ereates fifficultios in determining the optimum positions for transducers which onl? measure changes sctoss discrite sample ciareters.

In spite of existing difficulties, comparisons between (i) latometric measursments according to eqs. (10) through (13) with ring gauae readings converted to radial strains proved favorable. Maximut observed variations on rock salt amounted to $7 z a t \epsilon_{2}=-9.13$. In some cases the two sets of measurements agreed to within better than 2 o at $\epsilon_{2}=-7.58$. Finally, the comparison of $t$ ing gauge readings at midheight and at $1 / 3$ the 
samplo lenuth fror one end led to discrepancies bet..., 0.68 and $i 8:$ of the smillest observed values. The radiat $y$ train at $1 / 3$ lenath exceedor the center strains in four of nine axor:inents indicating a "double barrel" configuration. 


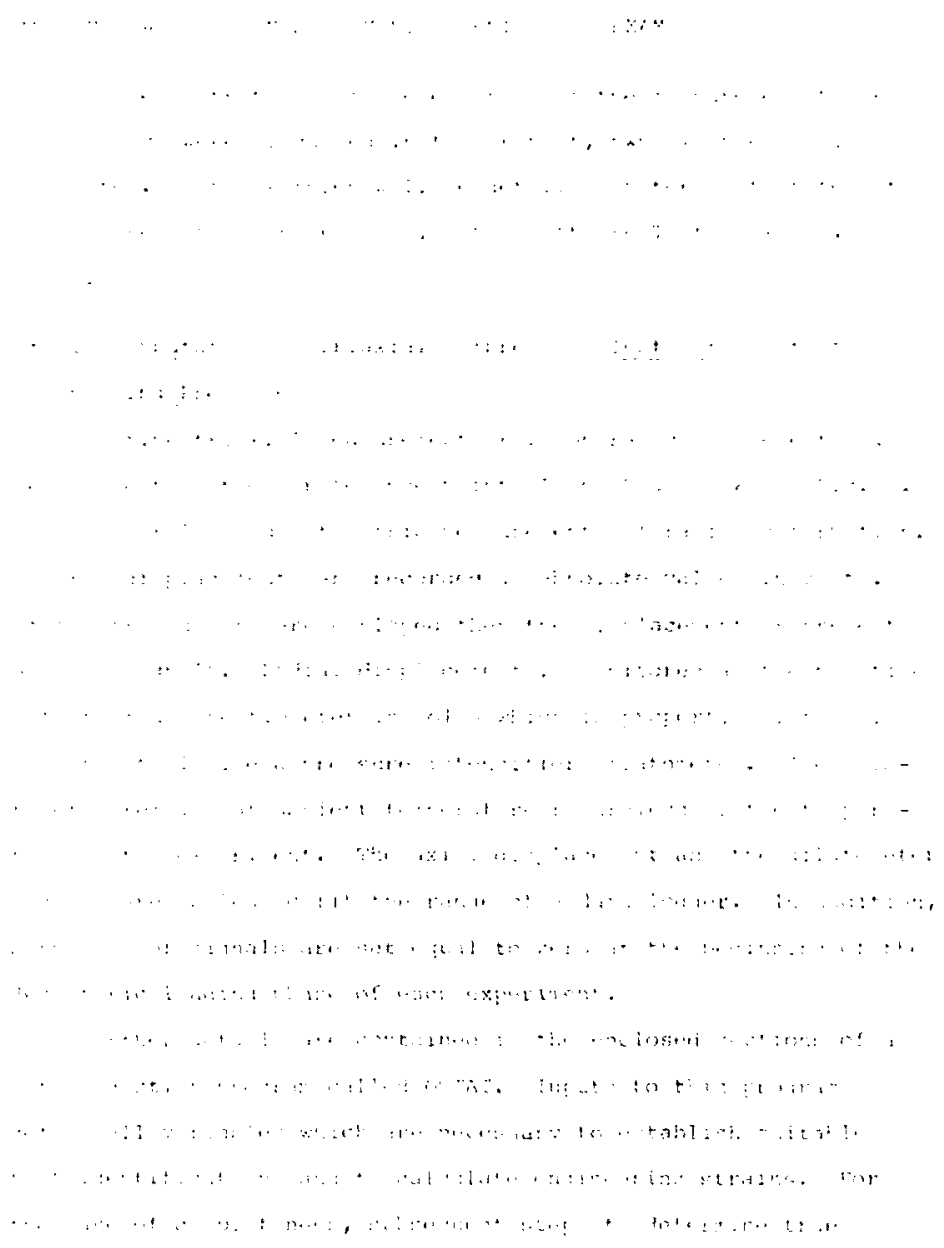




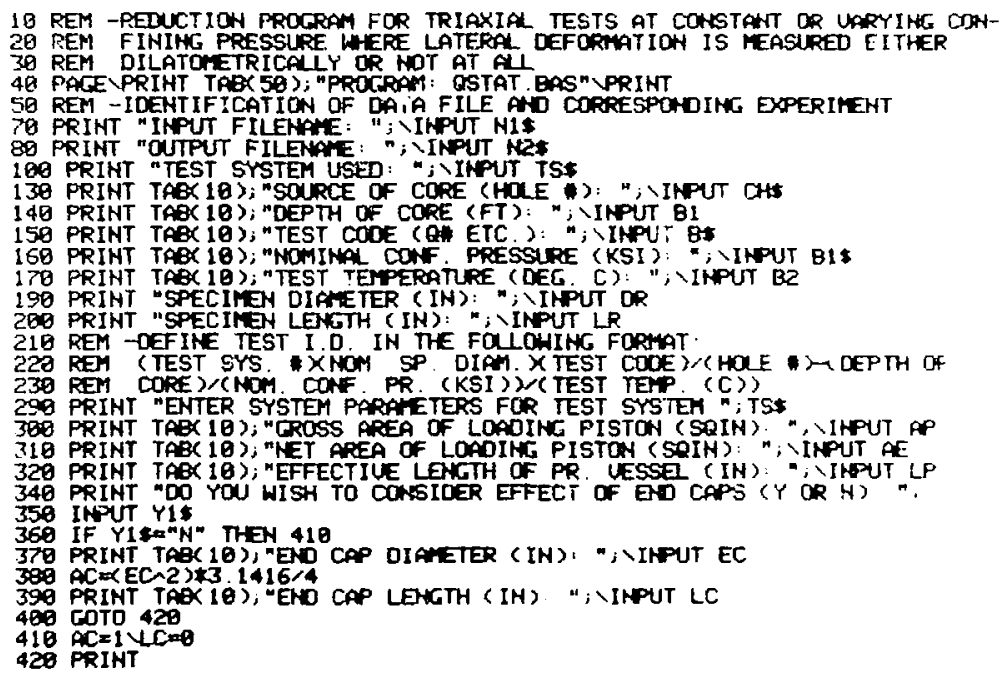




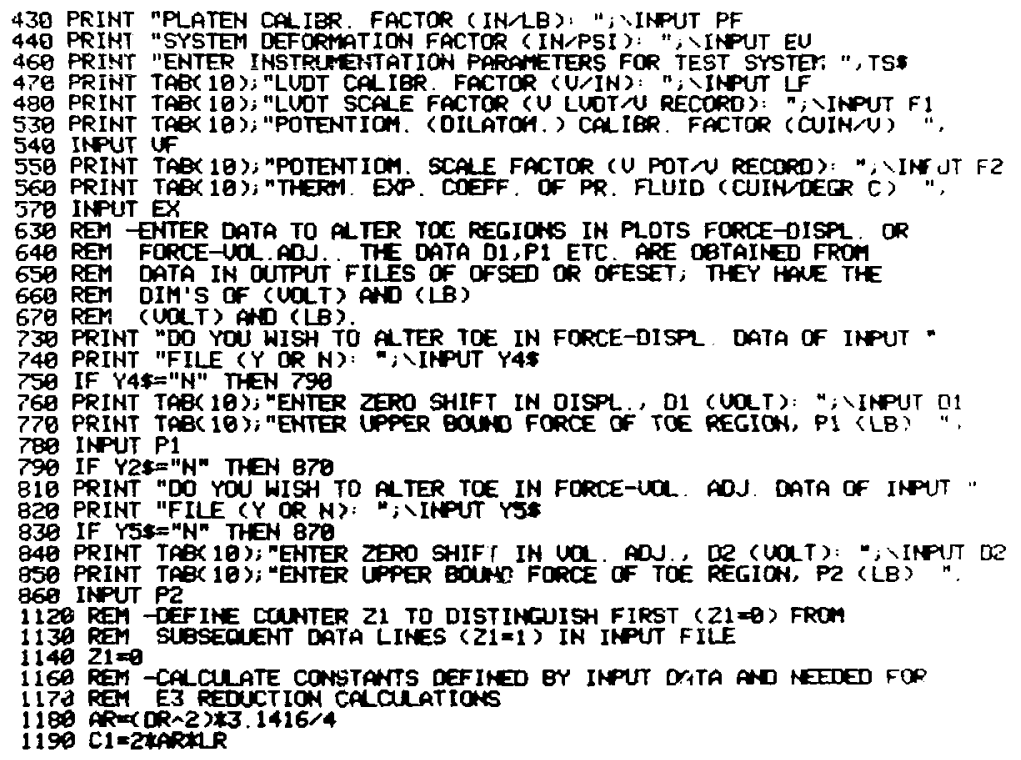


$1200 \mathrm{CZ}=(1-0 \mathrm{P} / \mathrm{PR}) / 2$

$1210 \mathrm{C} 3=.29 /(2.85+07402)$

1220 C4=LC* (AR-AP) (C1*2. EEtarkAC)

1230 C $5=C 3 *(C P \Lambda R)-1)$

$1240 \mathrm{TC}=(1-(\mathrm{BC}-22) \times \mathrm{EX})$

1250 REM BEEIN TO REAO PAD REOUCE DATA \&TITIHE; PADAD; CPICOAF, PR. 1260 REM $D=0 I S P L$; V=UOL ADJ.)

1270 INPUT $1, T I, P, C P, D, U$

13QS REM -CACULATE STRAIH EI (IN IN) COHSIDERIKE SHIFT FACTOR DI

1316 REM AND PLATEN DISPLACENENT

1320 IF P>P1 THEN IF P>P2 ThEN 1360

1330 If $\mathrm{Zl}=1$ THAN 1279

$1340 \mathrm{E} 1=0 \backslash \mathrm{E} 3=0$

1350 FTTO 1460

1362 DE(OADI ) NF) MF 1

1370 CP=P-CPNAE

1300 E1 $=00-C 7 \%$ F $-(C P-S R) * E U) M R$

1390 REM -CRLCULATE E3 CONSIOERING THERAL EXPANSION OF PR. FLUID AND

1469 REM SHIFT FACTOR Dz

$1420 \mathrm{U}=U+02$

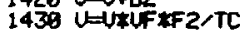

$1446 \operatorname{Cg} x U / C 1+(C 2-C 34)+E 1+(C 4-\operatorname{Cos}) 4 P)(1-E 1)$

1450 E3) $\operatorname{sek}(1+2+c 6)$ -

1460 REM CALCULATE SHER AND WOLUETRIC STRAINS

1460 REM CALCO

$1480 \mathrm{E}=1$ - E1 )

1499 REM EHLCLATE PRINC. STRESS DIFF, AND MEN STRESS

1500 CB-ARt $1+E 3)$ - 2

1510 S4-C7/CB

$15205 \times(84+300) / 3$

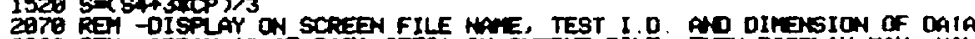

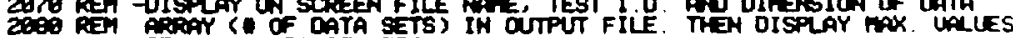
2090 Ray of TIRE, ( $81-83)$ ETC 


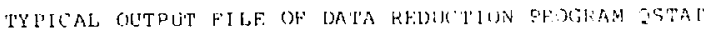

The abbreviated file name 030 designates the tile as an ou"put file or the data reciction arograr

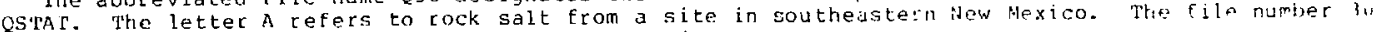
(between 0 and 99 ) identifies a guasistatic experiment.

FILE QA30

TEST I.D. Al 4Q,9-2604/5/200

\begin{tabular}{|c|c|c|c|c|c|c|c|}
\hline $\begin{array}{l}\text { TIME } \\
\text { (HRS) }\end{array}$ & $\begin{array}{l}\text { S1-S3 } \\
\text { (PSI) }\end{array}$ & (PSI) & $(P S I)$ & $\left(\begin{array}{l}E 1 \\
(X)\end{array}\right.$ & $\begin{array}{r}-E 3 \\
(\geqslant)\end{array}$ & $\underset{(*)}{E 1-E 3}$ & $\left(\frac{E}{1}\right)$ \\
\hline $\begin{array}{l}899, \\
8111, \\
0333, \\
8567, \\
1, \\
1375, \\
1667, \\
23 \\
2333, \\
2667, \\
2795, \\
2828, \\
2942, \\
3, \\
3333, \\
3667, \\
4, \\
4645, \\
4333, \\
4667, \\
5, \\
5333, \\
5392,\end{array}$ & $\begin{array}{l}600, \\
265, \\
265, \\
260, \\
263, \\
511, \\
516, \\
506, \\
569, \\
498, \\
527, \\
757, \\
763, \\
758, \\
747, \\
764, \\
757, \\
1611, \\
1606, \\
994, \\
1695, \\
1811, \\
1247,\end{array}$ & $\begin{array}{l}529, \\
527, \\
528, \\
529, \\
539, \\
528, \\
525, \\
526, \\
527, \\
527, \\
526, \\
517, \\
523, \\
524, \\
527, \\
524, \\
521, \\
524, \\
527, \\
524, \\
523, \\
527,\end{array}$ & $\begin{array}{l}529, \\
615, \\
616, \\
616, \\
618, \\
698, \\
697, \\
695, \\
694, \\
693, \\
792, \\
769, \\
777, \\
777, \\
776, \\
779, \\
773, \\
861, \\
862, \\
857, \\
839, \\
850, \\
943,\end{array}$ & $\begin{array}{l}600, \\
65, \\
655, \\
657, \\
697, \\
11, \\
112, \\
114, \\
114, \\
114, \\
132, \\
147, \\
149, \\
16, \\
165, \\
17, \\
236, \\
312, \\
355, \\
393, \\
476, \\
562,\end{array}$ & 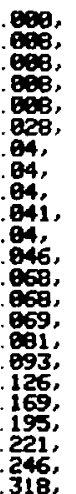 & $\begin{array}{l}609, \\
658, \\
864, \\
655, \\
855, \\
125, \\
15, \\
153, \\
155, \\
155, \\
154, \\
178, \\
214, \\
216, \\
229, \\
245, \\
263, \\
362, \\
48, \\
551, \\
614, \\
624, \\
88,\end{array}$ & 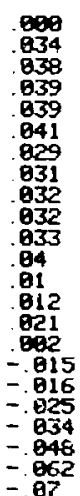 \\
\hline
\end{tabular}




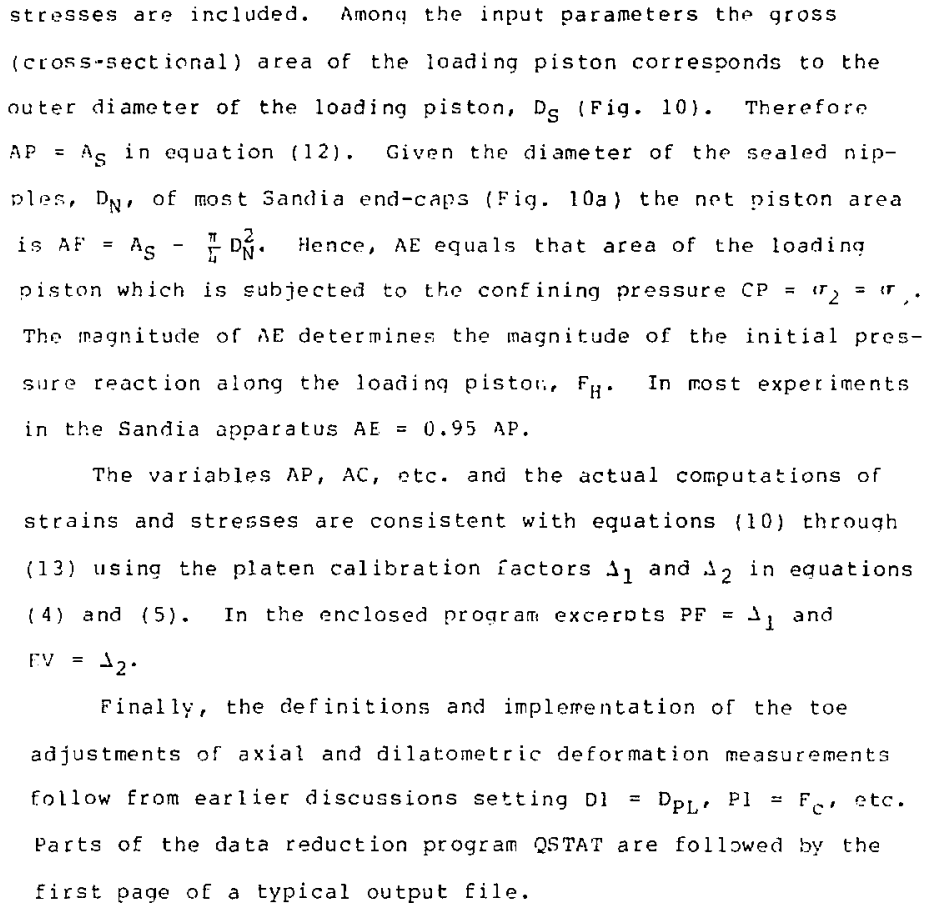




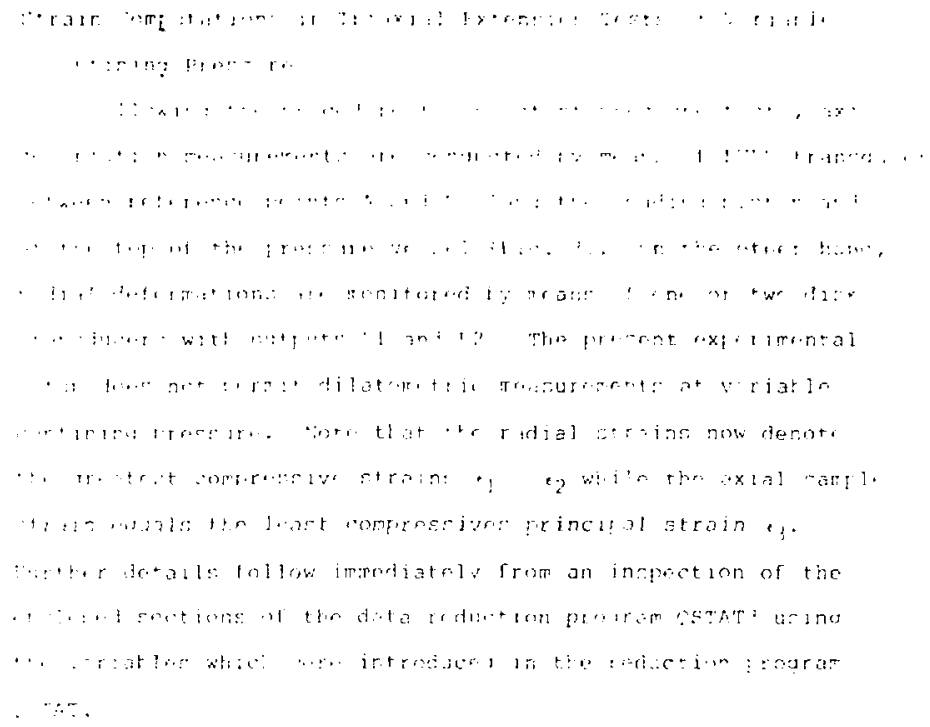


IO REM -REDUCTION PROGRAN FOR TRIAXIAL EXIENSION TESTS WHER LATERAL

20 REM STRAIN IS MEASURED BY MEANS OF ONE OR TWO DISC GAUCES

30 PACE \PRINT TAOK 50), "PROCRAM: QSTAT3. BAS" YPRINT

40 REM - IDENTIFICATION OF DATA FILE AND CORRESPONDINK EXPERIMENT

50 PRINT "INPUT FILENAN: " MINPUT N1"

60 PRINT "OUTPUT FILENATE: "; IIPUT HE*

80 PRINT "TEST SYSTEM USED: "NINPUT TSE

110 PRINT TAB 18); "SOURCE OF CORE (HOE $)$ : "; YINPT CHS

120 PRINT TAB 10); "OBPTH OF CORT (FT): "; IIFUT B1

130 PRIHT TAB 10); "TEST COOE (OA ETC.): "; पIMPUT B

140 PRINT TABX 19); "CONF PRESSURE (KSI): "i VINPUT BIS

150 PRINT TAO 10); "TEST TERERATURE (OEG. C): " NINPUT B2

179 PRINT "SPECIIEH DIAMETER (IN): "; INPUT DR

189 PRINT "SPECINEN LEXGTH (IN): ", INPUT LR

190 REM -DEFIKE TEST I.D. IH THE FOLLOWIMS FORHAT:

209 REM (TEST 5YS. XHOM. SP. DIAM. XTEST COOE)/ HOLE )-(DEPTH OF

210 REM CORE) $($ NOM. COF. PR (KST) $)($ TEST IEP (C))

270 PRINT "ENTER SYSTEM PARATETERS FOR TEST SYSTEM "; TSS

280 PRINT TAEX 10); "CROSS PREA OF LOADING PISTON (SQIN): "; INPUT AP

299 PRINT TABX 1B); "FLATEN CALIER. FACTOR (INLB). " INPUT PF

300 PRINT TAQX 10 3; "SYSTEM OFFORATIOH FACTOR (INPSI): * NINPUT EU

310 PRIHT

320 PRINT TABX 10); "LVOT CALIBR FRCTOR (WIW): "; IINUT LF

330 PRINT TABX 10); "LUDT SCALE FACTOR (U LUT TN RECORO): "; IHPUT F1

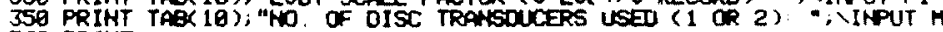
360 PRINT

378 PRINT TABX 15); "CALIER, FACTCR ( $(1 / N)$ FOR OISC 1 (CH. $x+4$ ): ",

360 IFUT UF

399 PRINT TAP(15); "SCALE FACTOR FOR DISC 1 (U DISCNU RECORD) " :

400 IPPUT F2

410 IF M I THEN 460

439 PRINT TABX 15); "CALIER. FACTOR (U/IN) FOR DISC E2 (CH $x+5)$ : :; 
440 INPUT WF

450 PRINT TABC 15); "SCAKE FACTOR FOR DISC "W2 (U DISC U RECORD): ";

468 INPUI F3 3 REM ENTER OATA TO ALTER TOE OF FORCE-AX. DISPL. CURVE DR TO

490 REM ZERO-SHIFT AUL AX. AND OR LAT. DISPL. UALUES. THE DATA

500 REM D1,P1 ETC. ARE DBTAINED FROM DATA IN CATPUT FILES DF

516 REM OFSED2 OR OFSET2; THEY WAVE THE DIM'S OF (UCT) AHO (LB)

540 PRINT "DO YOU HISH TO ALTER AX. OISPL. DATA OR TOE IN FORCE-OISPL ".

550 PRINT "OF INPUT FILE (Y OR $N)$ : : : INPUT Y $1 \$$

569 IF $Y 15=" N "$ THEH 609

570 PRINT TAB 19); "ENTER ZERO SHIFT IN DISPL,, D1 (UCRT): "; IIPUT DI

590 PRINT TABK 10); "ENTER UPPER BOUND FORCE OF TOE REGION, P1 (LB)." :

590 INPUT P1

600 PRINT

610 PRINT "DO YOU TO ZERO SHIFT LAT. DISPL. DATA (Y OR N): "; IINPUT Y2

62D IF 'YZ\$ $=" N "$ "THEN 689

630 PRINT TABY 16); "ENTER ZERO SHIFT IN LATD1 OATA (DISC \#1): ";

649 INPUT D2

659 IF $M=1$ THEN 710

6 FG PRINT TAB 19); "ENTER ZERO SHIFT IN LATOZ DATA (DISC *2): ";

679 INPUT D3

680 PRINT

699 PRINT "OO YOU HISH TO RETAIN ONY AUE LATD UALES CR BOTH INOIU "

7Q9 PRINT "AND AUC." YPRINT "UALUES (AN OR IN): "N IIFUT Y34

PIB PRINT

960 REM -DEFINE COWNTER $Z 1$ TO DISTINOUISH FIRST $(Z 1=\theta)$ FROM

950 REM SLBSEQUENT DATA LIKE $(Z 1=1)$ IN INPUT FILE

$970 \mathrm{Z1}=0$

1110 REM -CALCLLATE SAMPLE AREA

1120 ARE(DR-2)*3.1416/4

1130 REM EEǴIN TO READ AND REDUCE DATA (TETIHE; PAOAD; CP=CONF PR.

1140 REM $D=A X$. DISFL.; LI=LATOI; L2=LATD2)

1159 INPUT $1, T I, P, C P, O, L 1, L 2$

1160 IF $21=1$ THEN 1180

1170 costa 1946 
1180 REM -CALCULATE (AXIPL) STRAIN E3 (IN/IN) CONSIDERING SHIFT FACTOR

1190 RaM DI AND PLATEN OISPLACENaNT

1299 IF $P>P_{1}$ THEN 1230

1210 IF $21=1$ THEM 1150

1220 GOTO 1350

$12300=(0+01) / F) * 1$

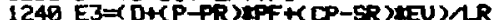

1250 REM - CALCULAT (LATEROL) STRAIN E1 COHSIDERIN POSSIELE SHIFT

1260 REM FACTORS De. D3

$1270 \mathrm{~L} 1=\angle 1+02$

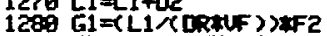

1299 IF $M=1$ THEN 1340

$1390 \mathrm{~L} 2=L 2+03$

1310 G2=(L2)(DRWF) ) *FF

$1320 \mathrm{E} 1=(\mathrm{G} 1+(\mathrm{C}) \mathrm{C}$

1339 GOTO 1350

$1340 \mathrm{E1}=\mathrm{G} 1$

1359 REM - CALCULATE SHEAR AND UOLUETRIC STRAIKS

$1360 \mathrm{E4}=\mathrm{E1}+\mathrm{E}_{3}$

$1379 \quad E=(1-E 1) \sim 2) *(1+E 3)-1$

138 REM - CALCULATE PRINC. STRESS DIFF. AND MEAN STRESS

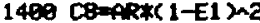

$141853=C P+(P-C P$ PP $) / C B$

1429 S4-CP-53

1430 se(2*84+3*53)/3

1430 Se(2*84+3453)/3

1940 REM -INITIAL LULE OFPRMIKATIONS

1960 SR=CP

1979 PR=P

2016 RETLRY

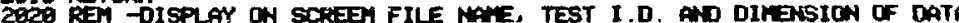

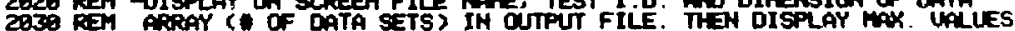
2040 Rey of TIRE, S4arsi-s3) ETC. 


\section{SUMMARY}

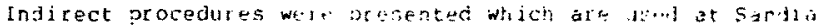

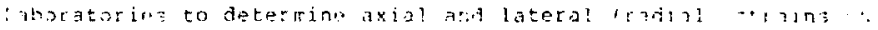

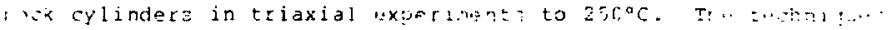

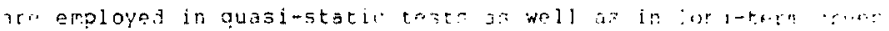
sxperisents. Descriptions if all tackniaues inclur.

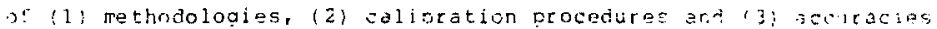

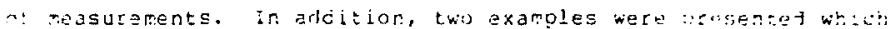

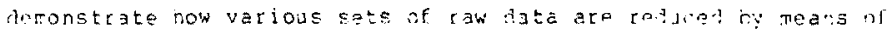
corouter prograns Eor triaxial cropession tasta an for triaxid oxtension experiments. 


\section{REEERENCES}

Baligh, M. M. "Numetical Study of Uniaxial and Triaxial Rock Compression Tests," Report No. SSS-R-73-1658, System, Science and Software, La Jolla, CA, 1973.

Fairhurst, C., "Laboratory Measurements of Soms Physical Properties of Rock, "Proc. 4th Symp. Rock Mech., Penn. State Univ., 1961.

Schuler, K. W., "Laterel-deformation Gage for Fok-mechanics Testing," Exper. Mech. 18, 12, 1978

Wawersik, K. R., "Technique and Apparatus for Strain Measurements on Rock at Constant Conf ining Pressure," Rock Mech., 7, 231, 1975. 


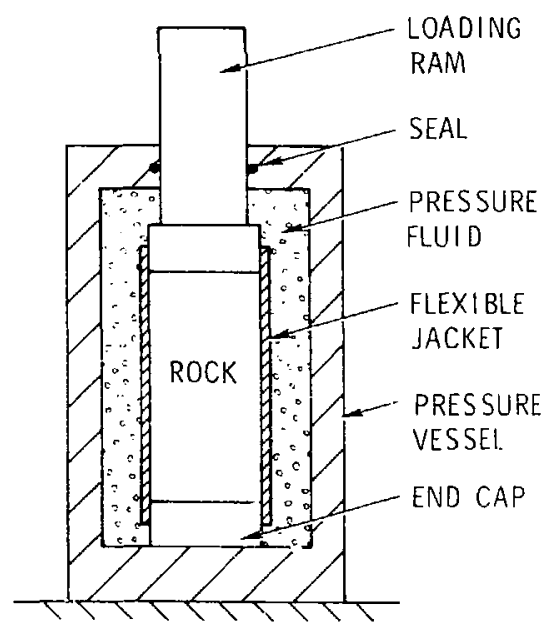

(a)

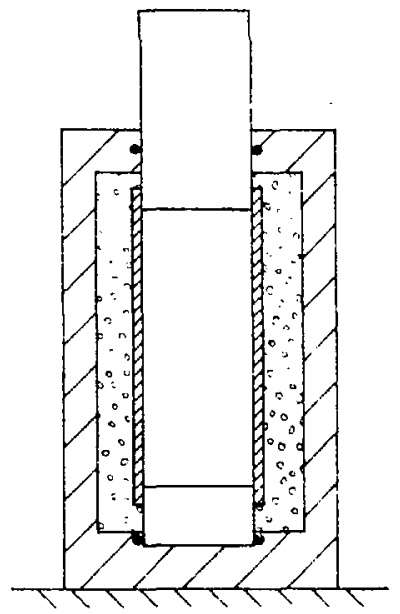

(b)

Fiaure 1 Topical experiment con: ifutation for la: triaxial compreseion and ar (b) Extaneion teste. 


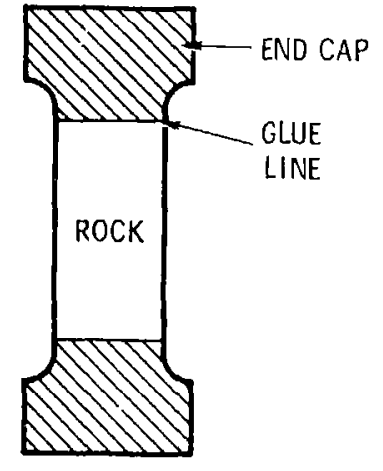

(a)

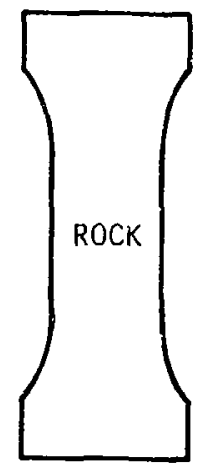

(b)

Figure 2 Fnd-cap and sample confiqurations used in some triaxial extensior experiments. 


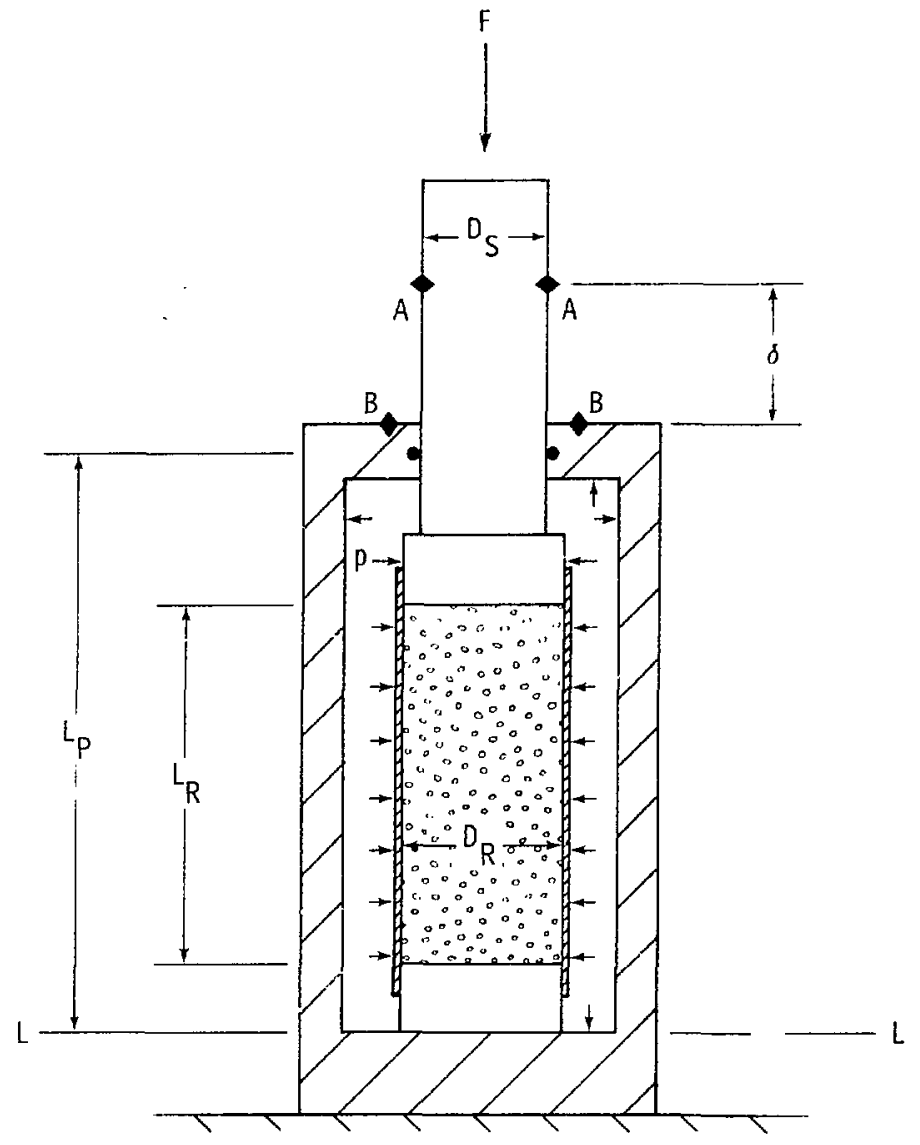

Figure 3 Schematic of system and transducer gauge points (pts. $A$ and $B)$ in Sandia triaxial apparatus. 


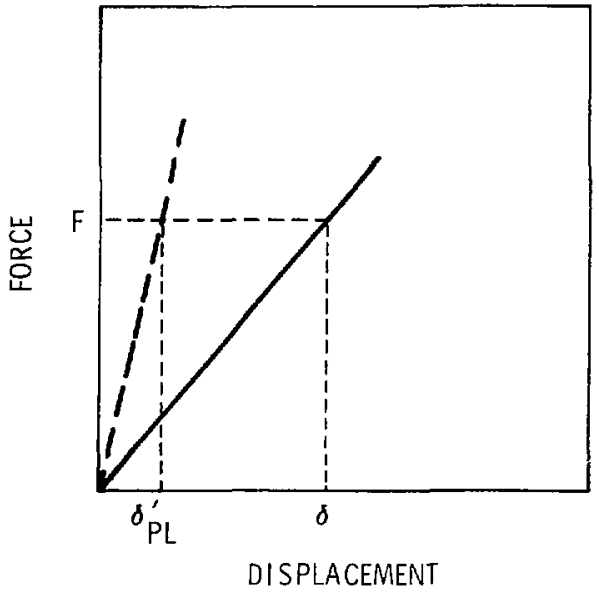

Eigure 4 Idealized (ram) force-displacement record, F versus $\hat{o}$ in Figure 3. 
$\stackrel{w}{\infty}$

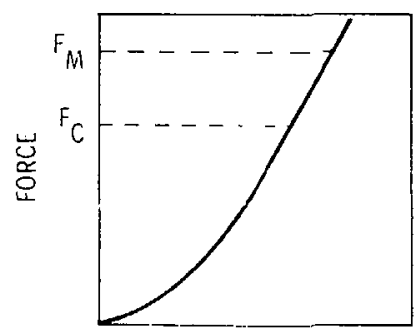

(a)

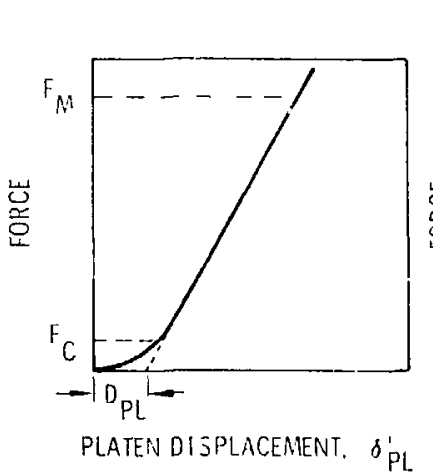

(b)

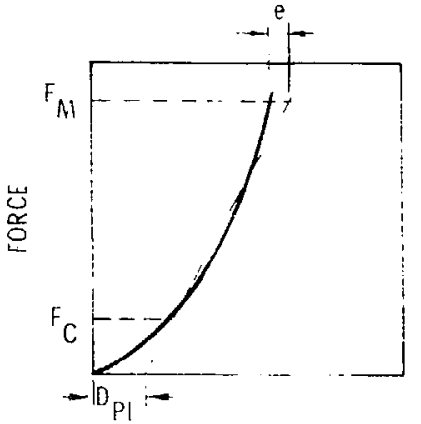

11

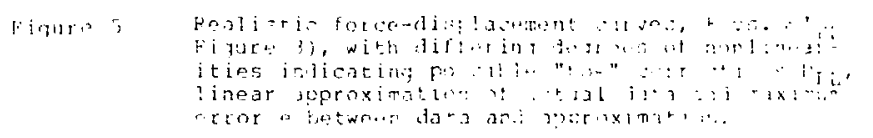



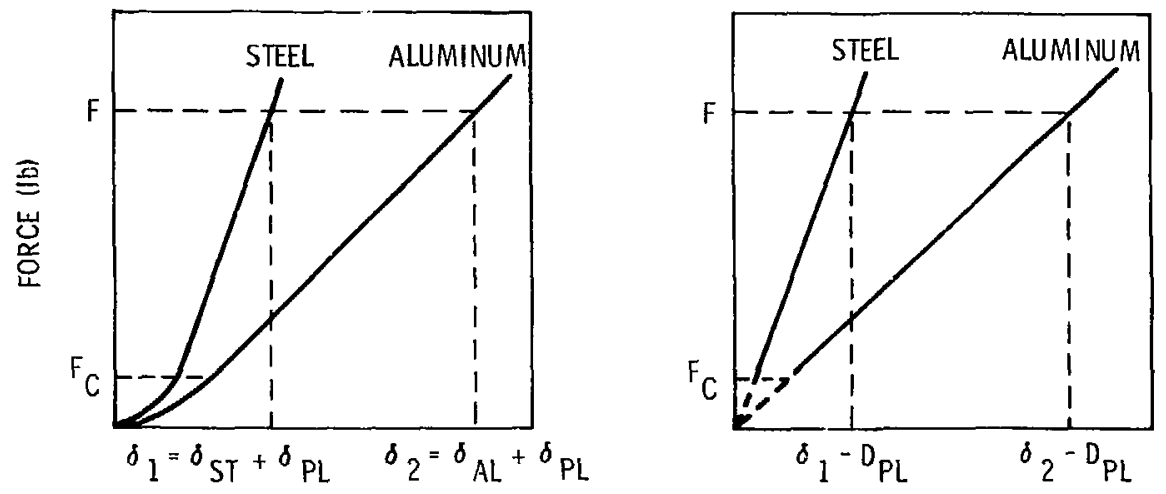

DISPLACEMENT (Volt)

(a)

(b)

Figure 6

Actual (a) and idealized (b) force disolacement curves for metal ctandards used in transducer and system calibrations. 


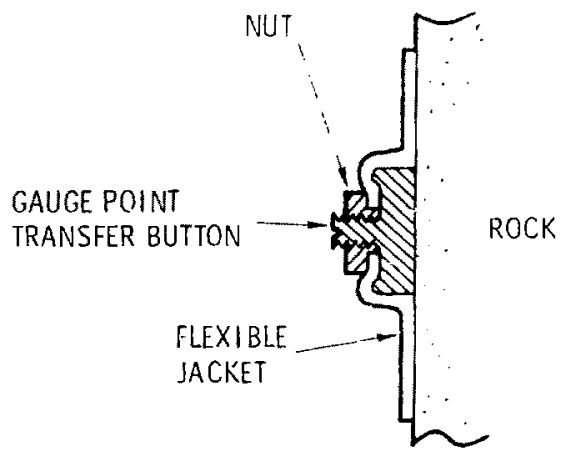

Fialue 7 Schematic of gauge point iransfer button for moasurament of radial samole derrimation. 

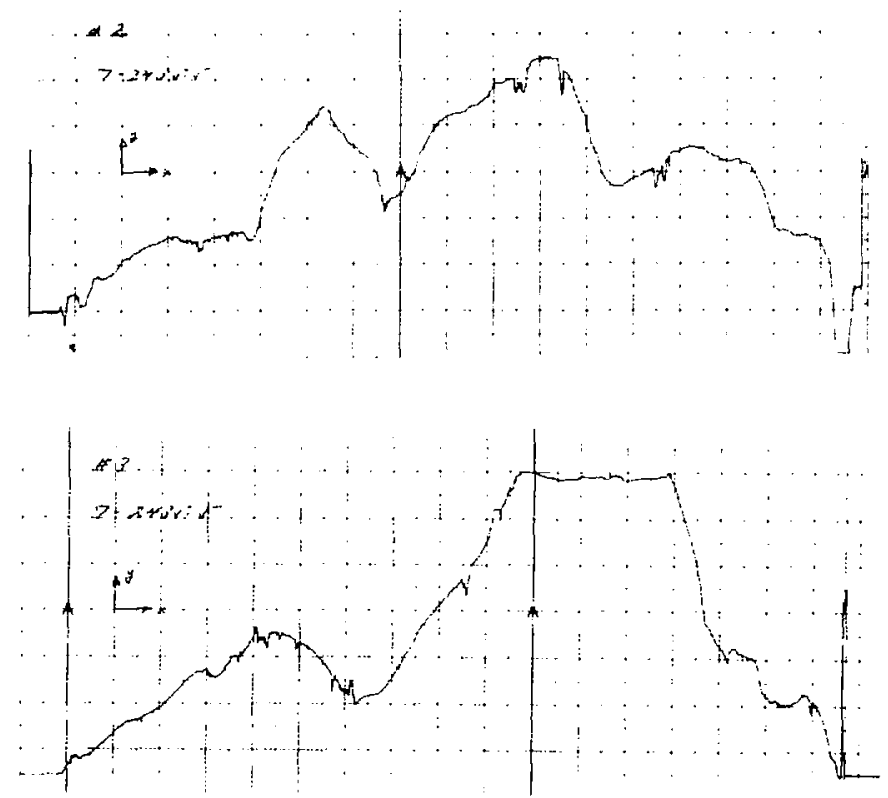

Fiqure 8 Typical surface profile of deformed rock salt specimen parallel to sample axis (direction of $\sigma_{1}$ )

$x$ : Distance from specimen ends

$y:$ Relative amplitude propgrtional to radial deformation ( $1.13 \times 10^{-3}$ in $(28.8 \mathrm{\mu m}$ ) per smallest division).

Records $\# 2$ and \#3 correspond to gauge lines $\frac{\pi}{4}$ radians apart. 


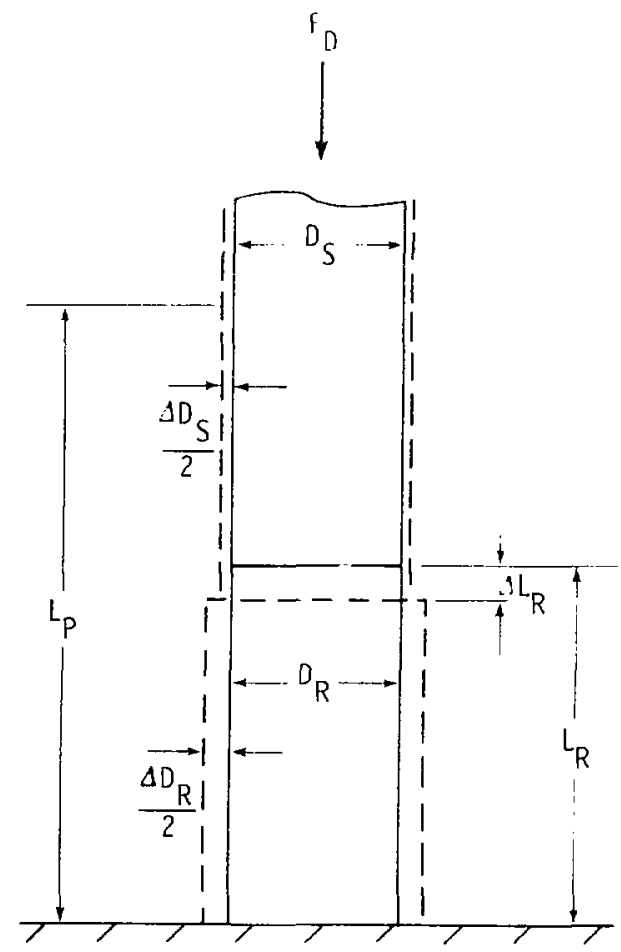

Figure 9 Schematic of triaxial sample - piston arrangement with matched diameters, $D_{R}=D_{S}$ for interpretation of dilatometric measurements. 


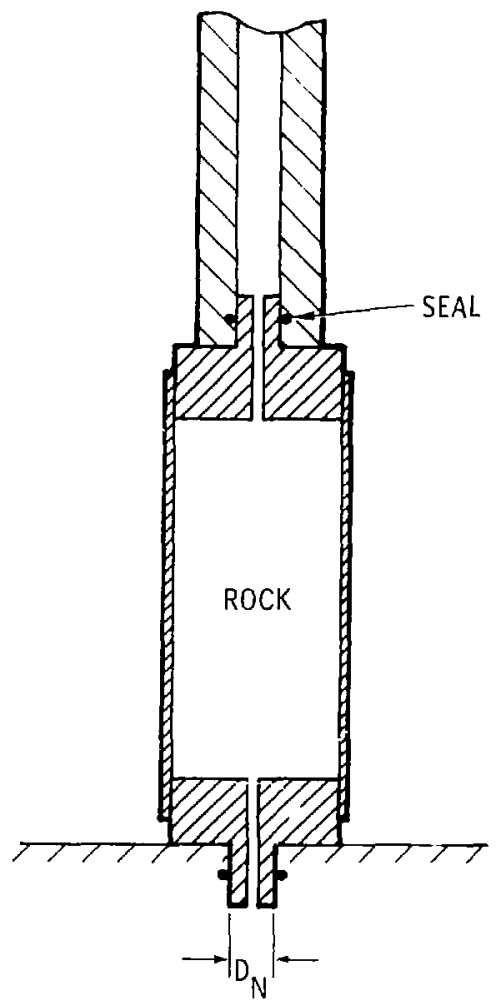

(a)

Figure 10 Schematic configuration of specimen, loading piston, and end-caps in Sandia triaxial apparatus. ports through piston and end-caps provide access to specimen for venting, pore pressure control, etc. 


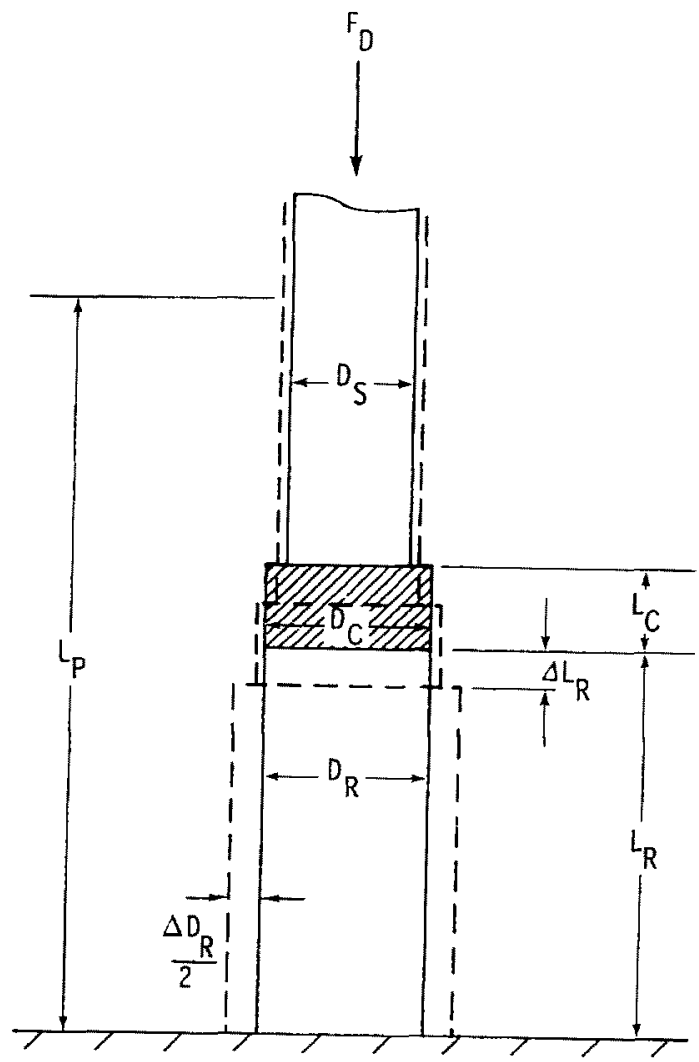

(b)

Fiqure 10 Schematic configuration of specimen, loading piston, and end-caps in sandia triaxial apparatus. Parts throngh piston and end-caps provide access to specimen for venting, pore pressure control, etc. 
U.S. Dept. of Energy, Headguarters

of ice of Nuclear Waste Management

bishington, DC 20545

Eugene F. Beckett, Project Coor. (wIPP) (5)

colin A. Heath, Cir., Div. Waste Isolation (2)

Sheldon Meyers

Raymond $G$. Romatowski

R. Stein

Carl F. Cooley

U.S. Dept. of Energy, Albug. Operations

P.O. Box 5400

Albuguerque, NM 87185

D. T. Schueler, Mgr., WIP $\overline{\text { Project }} \overline{\text { off }} \overline{\text { ice }}$ (3)

R. Rudolph, Ata. Deputy Mgr.. Wr Pp Project office

G. Dennis, Dir., Public Affairs Division

S. C. Taylor, C\&TI Div. (Public Reading Roons) (5)

U.S. Dept. of Ener $\exists Y$

Carlsiad WIPP Project office

Room 113, Federal Building

Carlsbad, NM 88220

Mr. JEEE O. NEEE

U.S. Deot. of Energy

c/o eattelle office of Nuclear

Naste Isolation

505 King Avenue

Columbus, OH 43201

Battelle Memorial Institute

office of Nuclear waste Isolation

505 King Avenue

Columbus, OH 43201

Neil Carter, General Manager $\overline{(2)}$

$R$. Heineman

Nayne Carbiner

Westinghouse Electric Corp.

P.O. Box 40039

Aibuquerque. NM 87196

R. C. Mairson

D. Hulbert

A. K. Kuhn, D'Appolonia

Mr. J. Holloway

National Academy of Sciences

Committee on Radioactive Waste Management

2101 Constitution Avenue

washington, DC 20418 


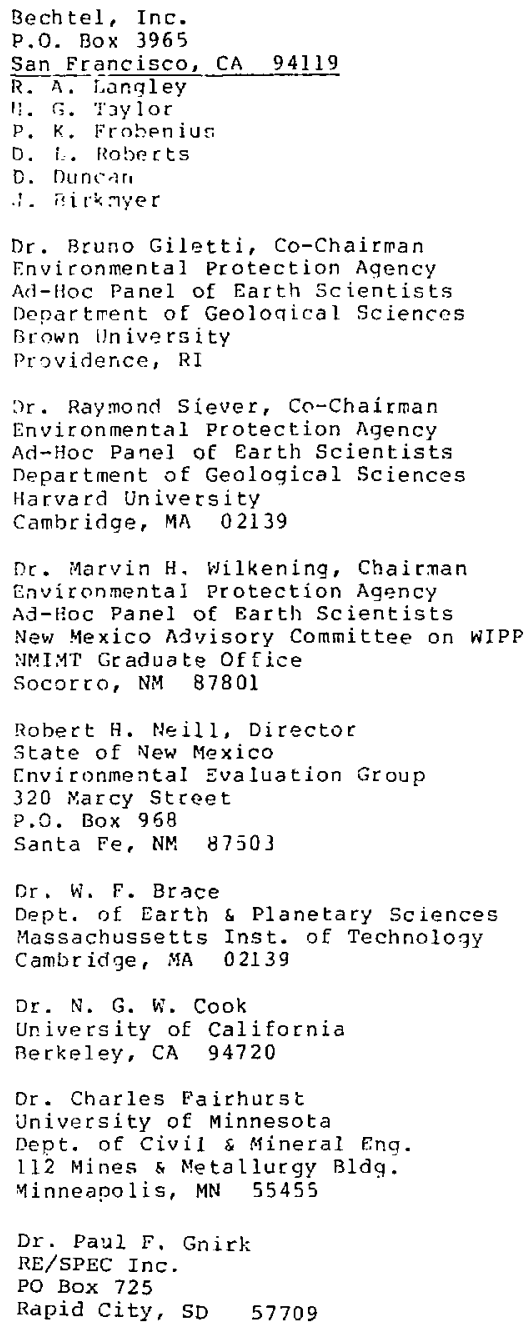




$\begin{array}{ll}3141 & \text { T. L. Werner (5) } \\ 3151 & \text { W. L. Garner, } \\ & \text { DOE/TIC (Unlim. Release) (3) } \\ 3172-3 & \text { R. P. Campbel1, DOE/TIC (25) } \\ 3310 & \text { W. D. Burnett } \\ 3311 & \text { D. R. Parker } \\ & \text { Attn: L. W. Erewer } \\ 3312 & \text { G. E. Tucker } \\ & \text { Attr: J. H. Metcalf } \\ 3313 & \text { A. L. Stanley } \\ 4500 & \text { E. H. Beckner } \\ 4510 & \text { W. D. Weart } \\ 4512 & \text { T. O. Hunter } \\ 4512 & \text { A. R. Sattler } \\ 4512 & \text { J. R. Wayland } \\ 4514 & \text { M. L. Merritt } \\ 4540 & \text { M. L. Kramm } \\ 4541 & \text { L. W. Scully } \\ 4541 & \text { R. E. Stinebaugh } \\ 4541 & \text { W. Wowak } \\ 4542 & \text { J. W. McKiernan } \\ 4542 & \text { Sandia WIPP Central Files (2) } \\ 4732 & \text { D. E. Munson } \\ 5000 & \text { J. K. Galt } \\ 5500 & \text { Attn: Directors } \\ & \text { O. E. Jones } \\ 5521 & \text { Attn: Department Managers } \\ 5530 & \text { W. Herrmann } \\ 5531 & \text { Attn: Supervisors } \\ 5531 & \text { P. D. Bertholf Dawson } \\ 5532 & \text { B. M. Butcher (2) } \\ 5532 & \text { L. S. Costin } \\ 5532 & \text { W. R. Wawersik (15) } \\ & \end{array}$

